\title{
Nordiques
}

38 | 2019

Le petit héros scandinave

\section{Challenging Bureaucracy Welfare Critique and Heroism in Mikael Engström's Isdraken}

Sotirios Mouzakis

\section{(2) OpenEdition \\ 12 Journals}

Electronic version

URL: http://journals.openedition.org/nordiques/294

DOI: $10.4000 /$ nordiques.294

ISSN: $2777-8479$

Publisher:

Association Norden, Bibliothèque de Caen la mer

\section{Printed version}

Date of publication: 1 November 2019

Number of pages: $73-83$

ISBN: 979-1-0959140-4-4

ISSN: 1761-7677

Electronic reference

Sotirios Mouzakis, "Challenging Bureaucracy Welfare Critique and Heroism in Mikael Engström's Isdraken", Nordiques [Online], 38 | 2019, Online since 31 October 2020, connection on 13 March 2021. URL: http://journals.openedition.org/nordiques/294 ; DOI: https://doi.org/10.4000/nordiques.294 


\section{Challenging Bureaucracy Welfare Critique and Heroism in Mikael Engström's Isdraken}

Sotirios Mouzakis*

\section{RÉSUMÉ}

Le roman de Mikael Engström, Isdraken, concerne une double fonction de l'héroüsme. Tout d'abord, le protagoniste Mik se voit attribuer des traits hérö̈ques au cours de son processus d'individualisation. Deuxièmement, l'héroïsme de Mik résulte de la nécessité de s'opposer à des mécanismes de protection sociale qui, malgré les bonnes intentions, constituent une menace et un danger pour son bien-être physique et psychologique et ne reconnaissent pas les besoins de l'individu au-delà du conformisme aux règles. Ces deux nuances interagissent et développent une image dynamique, mais précaire, de l'héroüsme. Cet imaginaire est établi par une voix polyphonique et par différentes situations narratives (du narrateur hétérodégetique omniscient à la troisième personne à l'autodégèse à la première personne, de l'expérience directe au journal). Les nombreuses références intertextuelles qui contribuent à la complexité de l'héroüsme et le situent dans un contexte supratemporel sont d'un intérêt particulier.

\section{ABSTRACT}

Mikael Engström's novel Isdraken takes up the twofold function of heroism. First, protagonist Mik is attributed heroic traits along the process of his individualisation. Second, Mik's heroism results out of the necessity to oppose welfare mechanisms that, though good in their intentions, pose a threat and danger to his psychological and physical well-being and fail to recognise the individual's needs beyond rule conformity. These two nuances interact and develop a dynamic, yet precarious image of the heroic. This imagination is modulded through a polyphonous narrative voice and different narrative situations (from heterodiegetic third person omniscient narrator to autodiegetic first person narration that spans from direct experience to diary entries). Of particular interest are the numerous intertextual references that contribute to the complexity of the heroic and situate it within a supratemporal context.

\footnotetext{
* Sotirios Mouzakis is a PhD student, Collaborative Research Center 948 "Heroes - Heroizations Heroisms" - Albert-Ludwigs (Universität in Freiburg). His research focuses on Scandinavian literatures and cultures and his recent publication is "Princess of a different kingdom. Cultural imperialism, female heroism, and the global performance of Walt Disney's Mulan and Moana" in Barbara Korte, Simon Wendt und Nicole Falkenhayner (Hg.), Heroism as a Global Phenomenon in Contemporary Culture, New York, Routledge, 2019, p. 61-80.
} 
Stereotypes about the Swedish welfare model include social security, generous health care and a well-functioning educational system that offers equal opportunities for all, independent of their gender, race or class. While these associations are partly true, the rigid mechanisms and proclaimed egalitarianism are far from the perfect image that is frequently promoted and cause frictions from time to time instead. The grey zones and loopholes of the welfare administration are thus oftentimes taken up in cultural products such as literature and movies. One of these is the young adult novel Isdraken by Mikael Engström. The aim of this paper is to show the ambiguous status the challenging welfare bureaucracy takes in this text. I understand 'challenging' in its double meaning: on the one hand, there are the challenges of bureaucracy that lead to welfare critique, and, on the other hand, there is protagonist Mik's protest against the same exact bureaucracy, which results among other things in the heroisation of an unlikely underdog.

His ears looked big. But it wasn't the mirror's fault. His ears were big. But they were the only thing that was big. He was the smallest in his class. Maybe the smallest fifthgrader in the entire school.

- Do only your ears grow? asked the school nurse for everyone to hear.

The entire class stood in line to be weighed and measured and a doctor with cold hands felt the boys' testicles in their pants.

- Do only your ears grow? ${ }^{1}$

Mik's tiny body does not seem to grow (except for his ears) and sets him apart from his age-peers. Not only does the use of superlative phrases to describe his height stress his status as an outsider but also does the doctor's exposure and emasculation in front of his classmates mark Mik as underdog. When Mik later on introduces himself in front of his new class in Selet, a small town in northern Sweden, he names the exceptional size of his ears after a short moment of doubt as his defining yet unheroic main feature. "My name is Mik and I am... damn small for my age and only my ears grow" 2 . The story begins in Solna, a precarious suburb in the northwest of Stockholm. Poverty and criminality mark the spatial setting and define the wider social framework. The story of Mik's family is on a microlevel foiled against this context. His father is an alcoholic, his mother has died years ago and his older brother Tony is a delinquent. Much reminiscent of Hippolyte

1 Mikael Engström, Isdraken, 2006, Stockholm, Rabén \& Sjögren, p. 7. All translations, unless indicated otherwise, are my own. "Hans öron såg stora ut. Men det var inte spegelns fel. Öronen var stora. Men det var det enda som var stort. Han var kortast i klassen. Kanske kortaste femman i hela skolan. - Är det bara öronen som växer? hade skolsyster sagt så alla andra hörde. Hela klassen haade stått på rad för att bli vägda och mätta, och en doktor med kalla händer kände på pojkarnas pungkulor nere i kalsongerna. - Är det bara öronen som växer?”

2 Ibid., p. 74. "Jag heter Mik och jag är ... jävligt liten for min ålder och det är bara öronen som växer." 
Taine's pioneering ideas during the period of the Modern Breakthrough, Mik's precarious underdog condition is defined by three factors: race, milieu, moment. Anastasia Gremm argues in this context that a child that grows in a family like Mik's is doubly powerless due to his lack of symbolical capital and his existential condition as a child subordinated to adults ${ }^{3}$.

It comes as no surprise that social services step in when the situation gets out of hand. Social workers Linda and Kent represent and personify the welfare state and its stiff mechanisms. They have the authority to take decisions on Mik's behalf and set the norms when it comes to define the right family values. Even though their intentions are good and they manage to get Mik out of the destructive home environment (away from the alcoholic father and criminal brother who both alike are unfit to provide for the young boy), they fail to identify Mik's actual needs. The way they handle Mik is inadequate and intimidates the boy. Narratively, they are fashioned after the model of a villain, i.e.: the unknown, dangerous, uncanny. Tony warns his brother not to let strangers in, specifically the authorities, as they might mean harm. Mik's experiences with the social workers trigger negative associations with his brother's arrest, their intrusion into his home, and his father's hospitalisation. Mik perceives Linda as a threat; her condescending demeanour compounds this assumption. She decides unequivocally what constitutes a functioning, 'real' family and in consequence, what is allegedly best for Mik's well-being. Linda's perspective is the only valid one; the authority vested in her by the welfare state sets her standards bindingly in stone, overruling Mik's account of his precarious everyday-reality. She is, in a way, the femme fatale who brings about mayhem and despair.

Hannelore Daubert identifies a transformation of roles and relationship patterns as well as a mutation of patriarchal structures within the family since the 1950s, topics Young Adult Fiction willingly takes up and problematizes ${ }^{4}$. Welfare bureaucracy does however not seem to have registered this shift and holds on to traditional, heteronormative patterns. The rules it adheres to are inflexible to the degree that Mik must not stay with his lesbian aunt Lena in Northern Sweden, despite the fact that she is the only family member in his life where he feels at home and can thrive prosperously. Clearly, the welfare state's insistence on the forced separation from child and ward is a critique of the blind obedience to rules, sacrificing the individual's well-being to bureaucratic compliance and

3 Anastasia Gremm, Das männliche Kind im zeitgenössischen Kinder- und Jugendroman, Ph.D. Dissertation, Københavns Universitet, 2013, p. 214.

4 Hannelore Daubert, "Familie" in Kurt Franz (ed.), Kinder- und Jugendliteratur. Ein Lexikon. Teil 6, 2015, p. 1. 
conventionality. The social workers show neither leniency towards Mik, nor do they take the time to listen and evaluate his problems. Mik's experience becomes a blind spot, overshadowed by institutionalised power relations. The plea for rainbow-families and the appreciation of a child as a person of his/her own will resonates implicitly throughout the entire course of the story in a queer subtext.

\section{FAILURE OF THE WELFARE INSTITUTIONS}

Social services fail on different levels, be it on the side of the officials who stubbornly execute the rules, or on the side of morality. Linda and Kent seem unfit to be working with children. They cannot sensibly handle the amount of responsibility that is invested in them by means of their position. Instead of listening to Mik and his needs, they perceive him as a troublemaker that they want to get rid of quickly and at any cost. Mik's articulation of his needs is unprecedented and has no corresponding regulation set in a catalogue of otherwise stiff standards. The foster family that Mik subsequently lives with turns out to be uncaring and unloving. Neither the parents nor the children offer him much-needed shelter instead tyrannizing the young boy by abusing him as work force instead. Rather than leaving chaotic and unstable circumstances behind, Mik must face physically and mentally abusive challenges anew. Furthermore, the classification of the foster family as apt environment for Mik copies the state's authority to decide over an individual from a macro level onto a patriarchal, heteronormatively and officially legitimised image of the ideal family on a microlevel. Official regulations, it seems, precede everything, even the individual's wellbeing.

When Mik is returned to his father's custody, neither the social workers nor the school-counsellor manage to become aware of the ongoing alcoholism the apparently sober father still suffers from. Analogously to the social workers, the school counsellor fails to react to Mik's problems and instead projects her ideals of a functioning family life onto him. She refuses to listen to him and only accepts the lies Mik tells her as satisfying truth about the allegedly harmonious everyday family life. As another official, she has neither the ability nor the volition to cope with circumstances beyond the state's and her own comfort zone. The power grown-ups have over children in Engström's novel is indicative of the lack of confidence in and respect for children's own perception and emotional response to critical situations. The mechanisms of the welfare state rely on rule-bound obedience and the ability of grown-ups to enforce rules and laws unconditionally and uncritically. Through the adults' eyes, the imagination of a picture perfect family is given preference over inconvenient realities that require an immediate intervention. The situation at hand requires individual evaluation, not schematic 
processing. While Mik lives in miserable circumstances in suburban Stockholm, neither the social workers nor the counsellor can adapt to his point of view or change their perspective in order to fully understand his situation. The counsellor does not acknowledge Mik's precarious condition. To the contrary, she ridicules his despair by contrasting his misery to her harmoniously idyllic upbringing in accordance with the welfare state's ideals and values. Withholding help and falsely evaluating Mik's situation, the counsellor's behaviour suggests she would much rather control him than enhance his situation. Observing these power hierarchies, the question of whether the poor and precarious are able to articulate themselves and can make their voices heard resounds anew, leaving a disheartening notion of disempowerment behind. Barbara Korte discusses the question of whether or not precarious voices can articulate themselves and make themselves heard. ${ }^{5}$ Referencing Gayatri Chakravorty Spivak's seminal "Can the Subaltern Speak?" (1988), Korte stresses in the context of postcolonial literatures, that "whether subalterns are granted opportunities to speak, and to be listened to, are questions of social and ethical relevance" . In the same fashion, the representation of poverty and precarity in Engström's novel analoguously triggers the "reader's social imaginary", while entitling the author to engage in a discourse he is not necessarily a part of, but that he nonetheless can raise his voice for.

Given the state's repeated failure when it comes to protecting Mik, the young boy sees no other option but to break out of his constraints and run away. His defiant behaviour entails the potential of disturbing the established order and canon of rules set by the legislation of the welfare state. The queer family constellation in Northern Sweden where Mik can thrive for the first time imposes a stark threat. The extent of the danger that originates from Lena's and Mik's recalibration of a core family becomes salient whenever the social workers appear and remind them of how above all, the laws and regulations must be upheld. Ultimately, Mik's appearance on the news and the manhunt that social services have initiated in order to catch him underline the erosion of a hegemonic welfare as caring provider for its individuals. At the same time, the inconvenient processes involved in child-care regulations reflect the absurdity of the entire scenario. Mik is powerless vis-a-vis the authorities and a captive of a rigid system whose ideology is rooted for the largest part in absolute equality with no room for individuality beyond a collective, dogmatically prescribed identity.

5 Barbara Korte, "Can the Indigent Speak? Poverty Studies, the Postcolonial and the Global appeal of Q\&A and The White Tiger", Connotations 20/2-3, 2010/2011, p. 293-312.

6 Ibid., p. 294.

7 Ibid., p. 295. 


\section{Heroism as Response to THE FaIlure of the Welfare STATE}

Against the misery caused by the welfare state, Mik's newly found family and friends in Selet are foiled as corrective. In this context, heroism figures in a twofold fashion: firstly, there is the underdog Mik who proves himself a hero (implicitly and explicitly) throughout the course of the novel when he must fight the injustices he constantly sees himself exposed to. I define an underdog following research conducted in the field of social psychology, as somebody who is precariously marginalised, disadvantaged compared to the top-dog and very unlikely to be successful in his or her planned enterprise. ${ }^{8}$ There are publications that noted that the underdog's struggle is per se heroic, ${ }^{9}$ while others state that underdogs "are a special sub-category of heroes" ${ }^{10}$.

Secondly, there are selected characters around him whose collective actions, such as signing a petition so Mik can stay with his aunt, elevate them to heroes fighting for a righteous cause. ${ }^{11} \mathrm{~A}$ hero is, according to the work of the Freiburg collaborative research centre on heroes, a human being who pushes boundaries by questioning existing conventions, overcomes obstacles for a greater good and often under pain of death, and who is considered or named a hero by his or her worshippers. ${ }^{12}$ Furthermore, a hero pools attraction and requires emotional responding. ${ }^{13}$

The novel's polyphonous narrator tells the story internally focalised through Mik's eyes and partially even in his voice. The authorities' failure in providing a safe environment for Mik to grow up in is set against Mik's coping mechanisms to deal with the unjust and larger-than-life challenges. Whenever he avoids defeat, he also emerges strengthened and is applauded for being a hero. His breaking the rules has nothing to do with revolting against the state. Instead, Mik defends himself against the inequalities he had to endure by the state and thus gains the moral high ground. The genre mix throughout the novel allows for Mik's

8 Scott Allison and Jeni Burnette, "Fairness and Preference for Underdogs and Top Dogs", in Roderick M. Kramer, Ann E. Tenbrunsel and Max H. Bazerman (eds.), Social Decision Making. Social Dilemmas, Social Values, and Ethical Judgements, New York, Routledge, 2010, p. 291-314.

9 Joseph A. Vandello, Nadav Goldschmied and Kenneth Michniewicz, "Underdogs as Heroes", in Scott Allison, George R. Goethals and Roderick M. Kramer (eds.), Handbook of Heroism and Heroic Leadership, New York, Routledge, 2017, p. 339-355.

10 Nadav Goldschmied, Jessica Ruiz and Sydney Olagaray, "The Underdog Narrative in Movies: When Our Memories Fail Us", Heroism Science 2/1, 2017, p. 1-11.

11 Olmo Gölz, who undertook an astute distinction between collectives of heroes ("Heldenkollektive"), heroic collectives ("heroische Kollektive") and collective heroism ("kollektives Heldentum").

12 Ralf von den Hoff et al., "Helden - Heroisierungen - Heroismen. Transformationen und Konjunkturen von der Antike bis zur Moderne", helden. heroes. héros. E-Journal zu Kulturen des Heroischen 1/1, 2013, p. 7-14.

13 Tobias Schlechtriemen, "Der Held als Effekt. Boundary work in Heroisierungsprozessen", Berliner Debatte Initial 29/1, 2018, p. 106-119. 
perspective to oscillate in all its facets. The novel begins with a third person narrator and shifts occasionally to diary entries and letters, both unmediated first person narratives that allow for an even closer and tighter identification with Mik. Of particular interest is Mik's zombie-diary, where the otherwise sociorealistic plot slips into the realms of fantastic literature. Creating a parallel world offers coping mechanisms to a child's struggles and problems that it otherwise cannot tackle. While the real life in its hardship takes place in the urban area of Stockholm, Selet serves as idyllic safe haven, a kind of an utopian enclave of full freedom without the reach of the State's control mechanisms ${ }^{14}$.

Selet is the romanticised escapist fantasy where Mik can be the child he is denied to be in Stockholm. The shift in the narrative voice reflects the spatial and psychological contrast.

Mik's desolate family life with his father and brother is described best in the Zombie-diary. Narrated in first person, Mik's inner feelings of uselessness and meaningless become tangible. Writing serves as a means of inner escape and coping strategy to the young boy to process the challenges life continuously serves him. As an underdog he is overwhelmed and paralysed by the seemingly larger than life obstacles. Writing these thoughts down and resorting into imaginative realms, Mik can break the rigour where he is trapped. Reminiscent of Charles Dickens's Oliver Twist (1837-39), his heroic action leads to a maturing process and inner growth while maintaining the status of an underdog. Telling his story in first person facilitates identification and, more importantly, keeps a potentially biased third person narrator at distance. Like that, the autodiegetic narrative voice is by means of emotional and perspective closeness both, more reliable and less manipulative at a time when it comes to steering the readers' sympathy. Because of the first person narrative, Mik can keep the underdog status that a third person could on the one hand most likely not maintain, on the other hand would most likely take away by explicitly proclaiming him a hero.

In part 5 of the novel there is a chapter entitled "En hjälte"15 ("A hero"). Applying Gustav Freytag's pyramidal scheme he developed for the structural analysis of drama onto the novel ${ }^{16}$, this last part clearly corresponds to the closure and features heroic action galore. When Mik has escaped from his foster family and temporarily returned to aunt Lena, he knows that his stay can only be temporary. In Freytag's logic this corresponds to the moment of final suspense during the falling action in the fourth act. Afraid of a future away from the Selet society, he and his friends take precautions and build a raft. The chapter opens by describing

14 Anastasia Gremm, op. cit., p. 213.

15 Mikael Engström, op. cit., p. 205.

16 Gustav Freytag, Die Technik des Dramas, Darmstadt, WBG, 1965, p. $102 \mathrm{ff}$. 
Mik's breakfast routine and the unusually big amount he eats. While organising their elopement, Mik recounts his adventurous journey ever since he left Selet for the first time and insinuates implicitly the heroic journey as proposed in Joseph Campbell's pivotal The Hero with a Thousand Faces. ${ }^{17}$

He told them everything he had been through. Killerdogs and dogshit. How he had been taken up by the police but was allowed to keep the biscuit chocolade and the coke. And how he burried a big fucking dog. Mik was a hero, no doubt, all three agreed on that. [...] None of them doubted what he said was true. Filip was a little hesitant about some details. ${ }^{18}$

Legitimised by the assessment of three friends, the narrator chimes in and explicitly awards Mik's actions heroic quality. The setup as proposed in the zombie-diary in part 3 and through the ordeals of part 4 (the title of which might be an allusion to the ten Egyptian plagues) results in concrete heroisation after all. Concluding the construction of the raft, one of the friends addresses Mik and reaffirms in unmediated direct speech "Du är en hjälte"19 ["You are a hero"] dispersing any last remaining doubt and putting an end to the previous episodes of probation. Like this, the dénouement is set in motion. The late heroic appellation suggests there is still more heroic action to come and foreshadows the ultimate adventure in Mik's journey. After having overcome Herculean obstacles there seems to be only one thing left for Mik to do: he needs to learn how to swim. This flaw adds a subversive notion to heroism and rather underlines Mik's status as an underdog.

Egalitarianism, as depicted in Isdraken, is a danger to society because the individual loses its right to well-being and to pursue happiness in the dehumanising machinery of a functioning welfare system. The state avoids supplementary, extracurricular measures and cares for grown-ups more than for children, which seem to be a mere projection ground for and perpetuation of ideologies. Mik actively tries to subvert potentially harmfull rules. Granted his actions are legitimate and pursue a higher good for which the reader deems transgressing boundaries morally acceptable, Mik's rebellion against the welfare state assures him the readers' empathy. Staked against all odds, the underdog's enterprise is upgraded and located into the realms of the heroic. Mik rises to the occasion and fights back in order to force a change of course. Heroism and

17 Joseph Campbell, The Hero with a Thousand Faces, Princeton \& Oxford, Princeton UP, 2004 [1949]. See specifically chap. 3 and 4 of part one, "The adventure of the hero", p. 179-236.

18 Mikael Engström, op. cit., p. 209f. "Han berättade om allt han varit med om. Mördarhundar och hundskit. Hur han blev tagen av polisen men fick behålla kexchokladen och colan. Och hur han begravt en stor jävla hund. Mik var en hjälte, ingen tvekan, det tyckte de alla tre. [...] Ingen av dem tvivlade på att det han sa var sant. Filip var lite tveksam till vissa detaljer."

19 Ibid., p. 211. 
brutality reciprocally foil one another. Mik's escapes seem even more spectacular in light of his presentation as feeble, for the most part innocent, and sensitive child with no agency to fight back whatsoever. His heroism feeds from the interplay of two major elements. Firstly, there are intertextual references that embed him within a specifically heroic supratemporal discourse. These references render the abstract opponent, the welfare state, more concrete by operating with more easily accessible imagery. Secondly, by overcoming the obstacles Mik actively shifts his status from an underdog into that of a hero and has the narrator vouch for the authenticity. For the most part, he does this completely on his own which lets his accomplishments shine even brighter. For example, there are episodes that bear striking similarity to the adventures of mythological Hercules. Mik clears the dung out of the foster family's dog pound, which is a parallel to the fifth labour of Hercules, who had to clean the Augean stables. The task is in both narratives thought impossible to achieve and humiliating in its nature. However, just like Hercules, Mik overcomes the obstacle heroically having fought his cynophobia and not given in to the pressure put on him by the cruel foster family. He even overcomes food deprivation, cold and being shot at by Niklas, the foster family's sadistic son.

\section{SOPHISTICATED HEROISM: INTERTEXTUAL REFERENCES AND ALLUSIONS}

While this reference establishes a timeless and culturally transcending framework of heroism, Engström furthermore situates his novel within the canon of YAF with explicit references to Astrid Lindgren's famous Bröderna Lejonhjärta (1973) and draws structural and textual parallels to the events taking place in Nangijala. Whenever Mik's fears of the welfare state or the people in its extension surface, the name of Tengil, the villain in the Lindgren novel, comes up as well. ${ }^{20}$ Mik's fight against the levelling welfare system provokes his heroism and is thus paralleled to Jonatan and Karl's battle against evil in their fantastic universe.

Closer to his Nordic origin and a possible interpretation of the novel's title are the allusions to Old-Norse deity Pórr and his combative encounters with the Midgard snake Jormungandr. For one, there is the imagery of fishing. Pórr catches Jormungandr on his hook but fights the sea monster in vain. A fearful giant Hymir cuts the rope and ultimately lets the monster escape. ${ }^{21}$ In contrast, Mik proves a more skilful fisherman. When he goes fishing with Bengt, Lena's elderly neighbour whom he befriends, he manages to pull out a big fish from lake Selet. ${ }^{22}$ When he is back in school, his report quickly alters the setting from

20 Ibid., p. 171f. where Tengil's name appears in connection with Mik's foster mother Eva, or p. 187 where Tengil is set in line with Linda and Kent, or p. 200 where Mik feels tracked by "Tengilsmän”.

21 Hymiskviða $\$ 23$ in Codex Regius, and Gylfaginning $\$ 48$ in Edda Snorra Sturlusonar.

22 Mikael Engström, op. cit., p. 97ff. 
a harmless fishing trip into an epic naval battlefield where Mik fought a giant sea monster tooth and nail. The deviation from the Old-Norse template is pivotal: Mik emerged victorious and can be sure of his classmates' admiration. Thus, even an underdog can become a champion when he or she is resourceful and clever. Mik overcomes his shortcomings and ennobles his underdog status by means of analogy that sets him in line with the Æsir. These encounters are heroically charged. Friederike Richter has convincingly pointed out the dangers as well as the potential for heroism that dragons entail in Old Norse literature. Mik's fight with the fish as well as with the welfare state can thus be read as his attempt to fight the "threat of the cosmological order" ${ }^{23}$, which is precisely what the Midgard snake represented.

Double referencing a god-hero, that is rooted deeply within European cultural and religious history in general and Scandinavian medieval culture in particular, and a brother-duo of a by now canonical classic of YAF, Engström weaves different discourses together and addresses more than just one implied reader. At the same time, the nearly infinite field of heroic elements serves him as a playground where he can mould his own literally little hero Mik by combining features that transcend one time period or one cultural context. The dramatic concluding scene on the frozen lake can be paralleled to Pór's final battle during Ragnarök just as well as to Astrid Lindgren's The Brothers Lionhear (Bröderna Lejonhjärta). The sea monster stings Pórr and poisons him fatally, as a result of which he will only be able to take nine more steps before dying. ${ }^{24} \mathrm{He}$ is deprived of agency and has to give in to his destiny. The allusions are a little more covert in this instance and require a somewhat broader contextualisation. Already in the third chapter of the first part into the novel, Mik, who cannot swim, articulates a wish to die by means of drowning during a swimming competition in school. Like a leitmotif, his inability to swim, which was parallelled to his exploits in the chapter "En hjälte" ("A Hero") and flaws his heroism, is entangled with his fascination for whales and their songs as medium of communication. The fact that whale songs can be heard when an individual whale has gotten lost and tries to reconnect with his herd is taken up multiple times just as well as the fact that some whales dive in dangerous depths when they want to take their own life. Additionally, the cracking of the ice layer on the frozen lake Selet produces a sound, which in Mik's perception is similar to the whale songs. In addition comes Mik's inner demon, which he distinctively names "Ormen Ensam"25 ("Dragon of solitude").

23 Friederike Richter, "Böse Blicke, Gift und Feuer. Drachenkämpfe am Beispiel der isländischen Gongu-Hrolfs saga sowie von Thors Fischzug”, helden. heroes. héros. E-Journal zu Kulturen des Heroischen: Faszinosum Antiheld 3/1, 2015, p. 124.

24 Völuspá $\$ 56$ in Codex Regius, and Gylfaginning $\$ 51$ in Edda Snorra Sturlusonar.

25 Mikael Engström, op. cit., p. 33. 
Taking these carefully scattered hints into account, the proximity to Pórr and his nemesis Jormungandr oscillates in yet another facet. Translating mythology into an everyday context, Jormungandr represents not only the fish in the lake but also Mik's anxiety and the welfare state's claws. Mik's wish to drown is certainly not heroic and rather indicative of his status as a disadvantaged, beaten underdog. When he is forced to run from the authorities again (his personal Ragnarök, so to speak), he escapes to the lake and walks on very thin ice, both figuratively and literally. But Mik will not drown, neither in lake Selet, nor in the depths of bureaucracy. Instead, he has learned to swim, especially against the tide. When he is on the brink of a hole in the ice layer covering lake Selet (and, unsurprisingly, on the verge of a nervous breakdown), he does not face an abyss of freezing water, but stands off his final enemy. Like Pórr, he was stung by bureaucracy's toxic spike and has only a few steps left to go. But unlike Pórr, he manages to go one step further, which is the decisive and victorious step in resisting the welfare state. He survives and through his newly found agency, he can cast off his underdog status and become a hero. When the water current draws him under the ice, death impending, Bengt, Mik's elderly friend, steps out of the parochial yet heroic crowd. His diligent reaction saves Mik's life when the authorities fail to. He dramatically holds up a mirror to the present welfare representatives who had pushed Mik to take extreme measures instead of conceding to the needs he so desperately tries to make them understand. Shaken by the prospect of being responsible for a young child's death, the officials finally admit defeat and it is implied that Mik finally gets to stay in Selet.

To the reader it seems that only death constitutes a limit the welfare officials are hesitant to transgress. Only when Mik's life is upright at stake, stiff laws and regulations can be suspended. While Mik's life unquestionably holds value for the authorities, they do not seem to either care about the quality that the environment they place him in has to offer or whether his corporeal integrity can be ensured. They work in full accordance to their rules and refuse to depart from their firm ideological conviction that what they are doing is actually right and the best for Mik - despite numerous voices of dissent. Bengt becomes the distinct face of the village community. Because he is on Mik's - and thus the allegedly right - side, the readers perceive his actions, his transgressive behaviour and his exceptional standing within the community as righteous and heroic. He saves the day and can restore the justice Mik is denied by the authorities. Ultimately, Mik's perseverance and his friends' courage to save him from the welfare state's rigid mechanisms prevail. Still, the ordeal he had to go through for a life in happiness is out of proportion. 